\title{
COMMENTS
}

\section{Rule 41(b) Dismissal as a Route to Appellate Review of an Adverse Class Determination}

When a district court denies a motion for certification of a class action pursuant to rule 23 of the Federal Rules of Civil Procedure, ${ }^{1}$ the representative plaintiff frequently seeks immediate appellate review of the adverse class determination. Such review is essential when denial of class certification results in a "negative incentive" situation, ${ }^{2}$ where the costs of litigating the individual claim outweigh the potential individual recovery. If the class is certified, the representative plaintiff can expect the class members to share litigation costs, rendering the suit economically feasible.

The Supreme Court has ruled, however, that the grant or denial of a motion for class certification under rule 23 is not a "final" decision ${ }^{3}$ subject to appellate review as a matter of right.. The Court also has held that the grant or denial of a motion for class certification is not appealable as an interlocutory injunctive order. ${ }^{5}$ These decisions foreclose immediate, nondiscretionary appellate review of the certification issue.

The representative plaintiff is left with five options, none of which is wholly satisfactory. He may first, apply for interlocutory review pursuant to section 1292 (b) of title 28 of the United States

1 In pertinent part, the rule provides: "As soon as practicable after the commencement of an action brought as a class action, the court shall determine by order whether it is to be so maintained. An order under this subdivision may be conditional, and may be altered or amended before the decision on the merits." FED. R. Crv. P. 23(c)(1).

2 See text and notes at notes 33-34 infra.

3 28 U.S.C. § 1291 (1976) grants federal courts of appeals jurisdiction over all "final" decisions of the federal district courts.

- Coopers \& Lybrand v. Livesay, 437 U.S. 463 (1978).

- Gardner v. Westinghouse Broadcasting Co., 437 U.S. 478, 480-82 (1978). Review of interlocutory orders "granting, continuing, modifying, refusing or dissolving injunctions" is provided for in 28 U.S.C. \$ $1292(a)(1)$ (1976). 
Code; ${ }^{\beta}$ second, apply for certification of the adverse class determination as a final judgment pursuant to rule 54(b) of the Federal Rules of Civil Procedure; ${ }^{7}$ third, apply for a writ of mandamus; ${ }^{\mathrm{s}}$ fourth, pursue the individual claim to a final judgment on the merits, then appeal from the final judgment; ${ }^{2}$ or finally, suffer a dismissal for want of prosecution pursuant to rule 41 (b). ${ }^{10}$ Under the first three options, jurisdiction is subject to the discretion of the court. A court cannot refuse jurisdiction under the fourth option, but the representative plaintiff cannot appeal until completion of a full trial on the merits of the individual claim-an unattractive course for a plaintiff in a negative incentive situation.

The approach most responsive to the needs of a plaintiff in this situation would be for him to follow the fifth option by refus-

- In relevant part, section $1292(b)$ states:

When a district judge, . . . shall be of the opinion that such order involves a controlling question of law as to which there is substantial ground for difference of opinion and that an immediate appeal from the order may materially advance the ultimate termination of the litigation, he shall so state in writing in such order. The Court of Appeals may thereupon, in its discretion, permit an appeal to be taken from such order ....

28 U.S.C. $\$ 1292$ (b) (1976) (emphasis added). See text and notes at notes 15-21 infra.

7 Rule 54(b) allows the district court to "direct the entry of a final judgment as to one or more but fewer than all of the claims or parties only upon an express determination that there is no just reason for delay and upon an express direction for entry of judgment". See text and notes at notes 22-26 infra.

- 28 U.S.C. $\$ 1651$ (1976); see text and notes at notes $27-29$ infra.

- The representative plaintiff's appeal of the final judgment would include a review of the denial of class certification. Deposit Guar. Nat'l Bank v. Roper, 445 U.S. 326, 336-38 (1980); Coopers \& Lybrand v. Livesay, 437 U.S. 463, 469 (1978) (dictum). This option is simply an application of the general rule that interlocutory orders merge into the final judgment. See generally Smith v. Illinois Bell Co., 270 U.S. 587, 588-89 (1926); Baldwin v. Redwood City, 540 F.2d 1360, 1364 (9th Cir. 1976); 9 J. Moore, Federal Practice I 110.18 (2d ed. 1980). See text and notes at notes 30-32 infra.

10 Rule 41(b) provides:

Involuntary Dismissal: Effect Thereof. For failure of the plaintiff to prosecute or to comply with these rules or any order of court, a defendant may move for dismissal of an action or of any claim against him. After the plaintiff, in an action tried by the court without a jury, has completed the presentation of his evidence, the defendant, without waiving his right to offer evidence in the event the motion is not granted, may move for a dismissal on the ground that upon the facts and the law the plaintiff has shown no right to relief. The court as trier of the facts may then determine them and render judgment against the plaintiff or may decline to render any judgment until the close of all evidence. If the court renders judgment on the merits against the plaintiff, the court shall make findings as provided in Rule 52(a). Unless the court in its order for dismissal otherwise specifies, a dismissal under this subdivision and any dismissal not provided for in this rule, other than a dismissal for lack of jurisdiction, for improper venue, or for failure to join a party under Rule 19, operates as an adjudication upon the merits. 
ing to proceed with the litigation after the denial of class certification. The district court, either sua sponte or on defendant's motion, would dismiss the suit with prejudice for want of prosecution pursuant to rule 41(b). ${ }^{11}$ This dismissal then would be appealable as a final judgment. The interlocutory denial of class certification would merge with the final judgment and it, too, would be subject to appeal.

Although a dismissal under rule $41(\mathrm{~b})$ may best meet the needs of a representative plaintiff in a negative incentive situation, this approach raises a host of theoretical problems. A court may be averse to granting final judgment status to a rule $41(\mathrm{~b})$ dismissal suffered solely to obtain review of an otherwise interlocutory order. This option arguably enables the plaintiff to circumvent the final judgment rule, thereby effectively expanding the scope of interlocutory review and burdening the judicial system with additional appeals that impede the administration of justice. On the other hand, rule 41(b) may allow a speedy and final determination of class status, thereby benefiting both plaintiffs and defendants in class suits. ${ }^{12}$

Even if a court allows review of the adverse class determination following the representative plaintiff's acquiescence in the rule 41(b) dismissal, the plaintiff faces a second problem. Because of the applicable standard of review, he must demonstrate that it was an abuse of discretion for the court to grant a dismissal that he deliberately provoked.

This comment assesses the alternative approaches to review of a denial of class certification, outlines a conceptual framework for analysis, and examines the arguments for and against review of adverse class determinations pursuant to rule 41(b) dismissals. It argues that such review should be permitted. Policy considerations demand it; moreover, it is consistent with the technical interpretation of the finality rule set forth by the Supreme Court in Coopers

1 Although rule 41(b) does not specifically allow involuntary dismissal by the district court sua sponte, it generally is accepted that the district court has that "inherent power." E.g., Link v. Wabash R.R., 370 U.S. 626, 630 (1962); accord, Janousek v. French, 287 F.2d 616, 620-21 (8th Cir. 1961).

${ }^{12}$ A rational defendant will spend more resources to defend against a potentially large class judgment than to defend a suit raised by an individual plaintiff with a small claim. The defendant, then, wants to know as early in the litigation as possible the size of the potential judgment so that he may adjust litigation expenses. Rule $23(\mathrm{c})(1)$ provides that the class certification should be decided "as soon as practicable after the commencement" of the suit. 
\& Lybrand $v$. Livesay. ${ }^{13}$ The comment concludes by assessing the practical problems of review following a rule $41(\mathrm{~b})$ dismissal and arguing that appellate courts should consider the dismissal in light of the adverse class determination. If this determination is found to be an abuse of discretion, the rule 41(b) dismissal should be reversed despite a representative plaintiff's acquiescence in it.

\section{Alternatives to Rule 41(b)}

In addition to seeking a dismissal pursuant to rule $41(\mathrm{~b})$, representative plaintiffs have four possible routes to appellate review of class certification denials. ${ }^{14}$ These alternatives fail to meet plaintiff's' needs, either because review is discretionary or because plaintiffs are unable to litigate the merits without prior resolution of class certification questions.

\section{A. Discretionary Options}

1. Section 1292(b). Courts and commentators have endorsed the interlocutory certification process under section $1292(\mathrm{~b})^{16}$ as an effective route to review of adverse class determinations. ${ }^{18}$ The same district court that denies the class certification motion, however, must be willing to certify the issue for appeal. ${ }^{17}$ In addition, the court of appeals has discretion to refuse to review a certified

13 437 U.S. 463 (1978).

14 See text and notes at notes 6-9 supra. This comment presupposes that a class of similarly situated plaintiffs seeks redress via the class action suit provided for in rule 23 . A group of plaintiffs might avoid the management and review problems involved in a class action by forming a not-for-profit corporation as a substitute for the class. The corporation would bring suit and the shareholder plaintiffs would have a stake in the outcome of the litigation. This comment does not consider this option, which provides a solution in some unusual situations. See generally Great W. Cities, Inc. v. Binstein, 476 F. Supp. 827 (N.D. IIl. 1979).

15 See note 6 supra.

${ }^{16}$ E.g., Deposit Guar. Nat'l Bank v. Roper, 445 U.S. 326, 336 n.8 (1980); Hooley v. Red Carpet Corp., 549 F.2d 643, 645 n.1 (9th Cir. 1977); Anschul v. Sitmar Cruises, Inc., 544 F.2d 1364, 1368-69 (7th Cir.), cert. denied, 429 U.S. 907 (1976); Parkinson v. April Indus., 520 F.2d 650, 655 n.5 (2d Cir. 1975); Katz v. Carte Blanche Corp., 496 F.2d 747, 756 (3d Cir.) (en banc), cert. denied, 419 U.S. 885 (1974); Kaplan, Continuing Work of the Civil Committee: 1966 Amendments to the Federal Rules of Civil Procedure (pt. 1), 81 Harv. L. Rev. 356, 390 n.131 (1967); American Bar Ass'n, Report of Special Comm. on Fed. Rules of Procedure, 38 F.R.D. 95, 104 (1965) [hereinafter cited as ABA Report].

${ }_{17}$ For the requirements for certification, see note 6 supra. The district court has complete discretion with respect to certification of the question, see ABA Report, supra note 16, at 104 , and therefore does not have to show cause for its denial of certification. 
interlocutory question. ${ }^{18}$ Because nearly one-half of the applications for leave to appeal under section 1292(b) are denied at the court of appeals level, ${ }^{19}$ not to mention the unknown number of requests for interlocutory certification denied at the district court level, section 1292(b) review is an inadequate substitute for appellate review as a matter of right.

Moreover, although class certification appeals turn heavily on an assessment of factual requirements, ${ }^{20}$ section $1292(\mathrm{~b})$ limits interlocutory appeals to "controlling questions of law."21 This requirement may foreclose reliance on section $1292(\mathrm{~b})$ as a route to appeal for many class certification questions.

2. Rule 54(b). Several courts ${ }^{22}$ have suggested that a denial of class certification will be appealable if the district court certifies the denial as a final judgment pursuant to rule $54(\mathrm{~b}) .^{23}$ This certification requires the district court to enter final judgment with respect to the absent class members upon denial of class certification. These absent class members then can appeal from that final judgment.

One advantage of rule 54(b) certification over section 1292(b) certification is that the courts of appeals cannot refuse to review a final judgment under rule 54(b). Like section 1292(b), however, the rule $54(\mathrm{~b})$ certification decision is made by the same district court that denies the class certification in the first instance. ${ }^{24}$ Moreover, courts have held that rule 54 (b) certification may not be used to

18 If the order is certified for review by the district court, the party applies to the court of appeals for leave to appeal. This application is reviewed by a screening panel. The court of appeals can deny review for any reason, including congested dockets. See S. REP. No. 2434, 85th Cong., 2d Sess. 3, reprinted in [1958] U.S. Code Cong. \& AD. News 5255, 5257; Hearings on H.R. 6238 and H.R. 7260 Before Subcomm. No. 3 of the House Comm. on the Judiciary, 85th Cong., 2d Sess. 21 (1958) (statement of Judge Maris). See generally Note, Interlocutory Appeals in the Federal Courts under 28 U.S.C. $\$ 1292(b), 88$ HARv. L. REv. 607 (1975).

19 Note, supra note 18 , at 607 n.5.

${ }^{20}$ See Fed. R. Crv. P. 23(a).

21 See note 6 supra.

${ }^{22}$ Gonzalez v. Texas Employment Comm'n, 563 F.2d 776, 777 (5th Cir. 1977) (per curiam); Monarch Asphalt Sales Co. v. Wilshire Oil Co., 511 F.2d 1073, 1077 (10th Cir. 1975); Samuel v. University of Pittsburgh, 506 F.2d 355, 360 (3d Cir. 1974); Katz v. Carte Blanche Corp., 496 F.2d 747, 752 (3d Cir.) (en banc), cert. denied, 419 U.S. 885 (1974); Hackett v. General Host Corp., 455 F.2d 618, 624 (3d Cir. 1972), cert. denied, 407 U.S. 925 (1973); Hayes v. Sealtest Foods, 396 F.2d 448, 449 (3d Cir. 1968) (per curiam).

23 See note 7 supra.

24 Rule 54(b) provides that the district court may direct a final judgment order. For a comparison with Section 1292(b), see text and notes at notes 15-18 supra. 
circumvent the final judgment rule, ${ }^{25}$ arguing that "[a] district court cannot by rule $54(\mathrm{~b})$ certification make final and appealable a ruling that is not final within the meaning of section 1291 with regard to the claim to which it applies." ${ }^{26}$ Because rule 54(b) combines the problems of discretionary review and questionable finality, it is ineffective in negative incentive situations.

3. Mandamus. Mandamus is a "narrowly circumscribed discretionary remedy"27 that should be used only where there is a clear showing of abuse of discretion. ${ }^{28}$ Given its extraordinary nature, it is not surprising that mandamus never has been issued to secure review of a class certification denial. The Supreme Court recently declared that mandamus should "hardly ever" be granted to review what otherwise would be an interlocutory order. ${ }^{29} \mathrm{Be}$ cause a class certification decision is an interlocutory order, mandamus is not a viable option for the representative plaintiff.

\section{B. A Nondiscretionary Option: Trial on the Merits}

If a suit can proceed to a final judgment on the merits of the individual plaintiff's claim, the adverse class determination can be raised on appeal of the final judgment. ${ }^{30}$ Although this option presents problems in fashioning the remand proceeding, ${ }^{31}$ the Su-

2s North Carolina Nat'l Bank v. Montilla, 600 F.2d 333, 334 (1st Cir. 1979) (per curiam) (dismissal of counterclaim with leave to amend); West v. Capitol Fed. Sav. \& Loan Ass'n, 558 F.2d 977, 982 (10th Cir. 1977) (appeal by named plaintiff of denial of class certification).

${ }_{28}$ North Carolina Nat'l Bank v. Montilla, 600 F.2d 333, 334 (1st Cir. 1979).

${ }_{27}$ Parkinson v. April Indus., 520 F.2d 650, 655 n.5 (2d Cir. 1975).

28 In re Cessna Aircraft Distrib. Antitrust Litigation, 518 F.2d 213, 217 (8th Cir.), cert. denied, 423 U.S. 947 (1975); Weight Watchers of Philadelphia, Inc. v. Weight Watchers Int'l, Inc., 455 F.2d 770, 775 (2d Cir. 1972).

28 Allied Chem. Corp. v. Daiflon, Inc., 101 S. Ct. 188, 190 (1980) (per curiam).

so See note 9 supra.

31 There are three options available to the appellate court on remand if it reverses an adverse class determination. At one extreme, the court could direct the district court to certify the class and extend the liability judgment to it. A new trial, limited solely to the question of class damages, would be necessary. This option is similar to one-way intervention, where class members are allowed to join in the judgment if the representative plaintiff wins, but are not subject to collateral estoppel if the representative plaintiff loses. See Kalven \& Rosenfield, The Contemporary Function of the Class Suit, 8 U. CHr. L. Rev. 684 (1941); Developments in the Law-Class Actions, 89 HARv. L. REv. 1318, 1394-1401 (1976). The elimination of one-way intervention was a major objective of the 1966 amendments to rule 23. See Fed. R. Crv. P. 23, Advisory Comm. Note, 39 F.R.D. 69, 105-06 (1966).

At the other extreme, the appellate court first could dismiss the named plaintiff as class representative. If putative class members did not then come forward to pursue the litigation, the case would be dismissed for lack of prosecution.

The third option is for the appellate court to remand the case to the lower court with instructions to certify the class and then to proceed with a trial de novo on the merits of the 
preme Court has endorsed this route to review. ${ }^{32}$

Proceeding to a trial on the merits, however, is not possible for the plaintiff facing a negative incentive situation, where litigation costs exceed the potential individual recovery. For example, where a class suit is brought on behalf of a class of five hundred merchants alleging that a distributor fraudulently overcharged the merchants, the class will seek damages in the amount of the overcharge plus some punitive figure. If each merchant claims $\$ 2,000$ in damages, the defendant is faced with a $\$ 1$ million suit. Where a full trial on the merits will cost the class $\$ 100,000$, each class member will bear $\$ 200$ in litigation expenses. So long as there is a ten percent chance that the class will prevail, this action will be economically feasible. ${ }^{33}$

If the class is not certified, the representative plaintiff faces a negative incentive situation. Although the litigation costs may decrease somewhat because the class is no longer present, the bulk of the expenditures still will be required to prove the individual claim. Even if the costs decrease to $\$ 50,000$, the individual plaintiff still stands to gain only $\$ 2,000$. By pursuing his individual claim to a full trial on the merits, the plaintiff must bear the entire litigation expense and will lose at least $\$ 48,000$. It does not matter whether the defendant is, in fact, guilty of the allegations; it does not even matter that the named plaintiff has a one hundred percent chance of winning the suit. In negative incentive situations, defendants are effectively judgment proof because no one individual can afford to prosecute the claim. Once the class is decertified, the representative plaintiff no longer has any incentive to pursue

class claim. The litigation would be returned to the position it was in when the class certifcation was erroneously denied. See, e.g., Cameron v. E.M. Adams \& Co., 547 F.2d 473, 478 (9th Cir. 1976).

s2 Deposit Guar. Nat'l Bank v. Roper, 445 U.S. 326, 336 (1980); Coopers \& Lybrand v. Livesay, 437 U.S. 463, 469 (1978); United Airlines, Inc. v. McDonald, 432 U.S. 385, 393 (1977). Even if the named plaintiff prevails on the merits of the individual claim, the Supreme Court has implied that he can raise the denial of class certification on appeal. In Roper, the Court held that a final judgment in favor of the representative plaintiffs of a class "did not moot their private case or controversy, and that respondents' individual interest in the litigation . . . is sufficient to permit their appeal of the adverse certification ruling." 445 U.S. at 340 (emphasis in original).

${ }^{33}$ If there is a ten percent chance of winning a $\$ 2,000$ claim, the expected value of the claim is $\$ 200$, which is the cost of each class member's share of the litigation expenses. With a ten percent chance of winning, the risk neutral class member will have no net gain or loss after attorney's fees are paid. If the expected value of the suit is $\$ 201$, the suit is profitable and there is an incentive to proceed. 
the individual claim..$^{34}$ The adverse class determination effectively marks the end of the litigation. The representative plaintiff therefore must seek immediate review of the denial of class certification to reinstate the class and revive the suit.

\section{A Conceptual Framework gor Analyzing the Finality RuLE}

The Supreme Court has noted that "in deciding the question of finality the most important competing considerations are 'the inconvenience and costs of piecemeal appeals on the one hand and the danger of denying justice by delay on the other.' "\$s While emphasizing congressional opposition to piecemeal appellate disposition because of its "enfeebling" effects on judicial administration, ${ }^{38}$ the Court has been willing to expand the scope of the final judgment rule to avoid injustice. ${ }^{37}$ The boundaries of that rule, however, are the subject of recurrent tension and confusion. This part of the comment develops a conceptual framework by which to examine the case law.

The Court long has required that the final judgment rule embodied in section 1291 be given a "practical rather than a technical construction." ${ }^{38}$ Although this requirement stems in part from the tensions between judicial efficiency and avoiding injustice by delay, it also reflects the difficulty the Court has had in defining the term "final judgment."s Under the Court's benchmark definition of

s4 The representative plaintiff faces what may be termed either a positive incentive to abandon the suit or a negative incentive to proceed. One way to find out whether a representative plaintiff will continue to litigate after the denial of class certification is simply to ask. See Bowe v. First of Denver Mortgage Investors, 562 F.2d 640, 643 (10th Cir. 1977); Lamphere v. Brown Univ., 553 F.2d 714, 718 (1st Cir. 1977).

3s Gillespie v. United States Steel Corp., 379 U.S. 148, 152-53 (1964) (quoting Dickinson v. Petroleum Conversion Corp., 338 U.S. 507, 511 (1950)).

${ }^{38}$ Cobbledick v. United States, 309 U.S. 323, 325 (1940).

${ }^{27}$ See, e.g., Eisen v. Carlisle \& Jacquelin, 417 U.S. 156 (1974); Gillespie v. United States Steel Corp., 379 U.S. 148 (1964); Cohen v. Beneficial Indus. Loan Corp., 337 U.S. 541 (1949). But see Coopers \& Lybrand v. Livesay, 437 U.S. 463 (1978); Abney v. United States, 431 U.S. 651 (1977); DiBella v. United States, 369 U.S. 121 (1962); Catlin v. United States, 324 U.S. 229 (1945); Cobbledick v. United States, 309 U.S. 323 (1940). For the early history of the final judgment rule, see Crick, The Final Judgment as a Basis for Appeal, 41 YaLE L.J. 539 (1932).

ss Cohen v. Beneficial Indus. Loan Corp., 337 U.S. 541, 546 (1949), quoted in Eisen v. Carlisle \& Jacquelin, 417 U.S. 156, 171 (1974) and Gillespie v. United States Steel Corp., 379 U.S. 148, 152 (1964). See also Cobbledick v. United States, 309 U.S. 323, 328-29 (1940); United States v. River Rouge Improvement Co., 269 U.S. 411, 414 (1926).

3o See Frank, Requiem for the Final Judgment Rule, 45 TEx. L. REv. 292, 295-98 (1966). Justice Black outlined the Court's problem in determining the finality of a decision 
finality, a judgment is indisputably final, and thus subject to appeal, if the decision "is one which ends the litigation on the merits and leaves nothing for the court to do but execute the judgment."40 This comment will refer to such an indisputable final judgment as a "technical" final judgment. There are additional decisions that arguably are final judgments because they terminate the litigation for all practical purposes, but in which the court has the option of doing more than merely executing the judgment. This comment will refer to such judgments as "practical" final judgments.

A continuum of finality can be established with technical final judgments at one terminal and practical final judgments at the other. The closer a judgment is to the technical terminal, the more likely it is that a court will review the decision; the closer the judgment is to the practical end, the less likely it is that a court will review it. On this continuum, a dismissal under rule $41(\mathrm{~b})$ is a technical final judgment because once a suit is dismissed for want of prosecution, the litigation is terminated, and the court's only duty is to enter the dismissal order. ${ }^{41}$

Standing by itself, an adverse class determination is not a technical final judgment because it is subject to revision by the district court,,$^{42}$ and the individual claim remains viable. In negative incentive situations, an adverse class determination constitutes a practical final judgment. ${ }^{43}$ The difficult question is whether a rule 41(b) dismissal, purposely suffered by a plaintiff in a negative incentive situation to obtain review of the class certification denial, should constitute a technical or a practical final judgment. If it is neither, courts must place this form of judgment somewhere along

as follows:

[O]ur cases long have recognized that whether a ruling is "final" within the meaning of section 1291 is frequently so close a question that decision of that issue either way can be supported with equally forceful arguments, and that it is impossible to devise a formula to resolve all marginal cases coming within what might well be called the "twilight zone" of finality. Because of this difficulty this Court has held that the requirement of finality is to be given a "practical rather than a technical construction."

Gillespie v. United States Steel Corp., 379 U.S. 148, 152 (1964) (quoting Cohen v. Beneficial Indus. Loan Corp., 337 U.S. 541, 546 (1949)).

10 Catlin v. United States, 324 U.S. 229, 233 (1945).

1 See Wilson v. Republic Iron \& Steel Co., 257 U.S. 92, 96 (1921); Bowe v. First of Denver Mortgage Investors, 613 F.2d 798, 799 (10th Cir.), cert. denied, 447 U.S. 906 (1980); Huey v. Teledyne Inc., 608 F.2d 1234, 1237-38 (9th Cir. 1979); Hick v. Bekins Moving \& Storage Co., 115 F.2d 406, 409 (9th Cir. 1940); Ruff v. Gay, 67 F.2d 684, 684 (5th Cir. 1933), aff'd, 292 U.S. 25 (1934); 5 J. MooRE, supra note 9, I 41.11[2].

${ }^{12}$ Such revision is available pursuant to Fed. R. Civ. P. 23(c)(1). See note 1 supra.

1s See text at note 59 infra. 
the continuum and determine if it is sufficiently final to warrant appellate review.

\section{The Impact of Livesay on Rule 41(b) Finality}

In Coopers \& Lybrand v. Livesay, 44 the Supreme Court held that a denial of class certification is not sufficiently final to be reviewed under section $1291 .^{45}$ The Court also held that an adverse class determination cannot be reviewed under the collateral order exception to section $1291 . .^{48}$ Two courts of appeals have construed Livesay to preclude appellate review of a rule 41 (b) dismissal taken purposely to review an adverse class determination, arguing that Livesay's policy against piecemeal appeals otherwise would be circumvented by a jurisdictional ploy. ${ }^{47}$ Examination of Livesay and its progeny demonstrates, however, that this construction of Livesay is not justified. The fact that the $41(\mathrm{~b})$ dismissal concludes the individual as well as the class claim ensures that this route to review will not be chosen casually as a means of avoiding the final judgment requirement. ${ }^{48}$

\section{A. Pre-Livesay}

Eisen v. Carlisle \& Jacquelin ${ }^{48}$ set the stage for Livesay. In that case the Second Circuit gave a practical construction to section 1291, establishing the "death knell" doctrine ${ }^{50}$ as an exception to the final judgment rule. In Eisen, a textbook example of the negative incentive situation, the plaintiff sued on behalf of a class of all traders in odd-lot stocks ${ }^{51}$ on the New York Stock Exchange. The suit alleged that the defendants, two odd-lot dealers, had con-

44437 U.S. 463 (1978).

4s Id. at 477 .

16 Id. at 469 .

17 Bowe v. First of Denver Mortgage Investors, 613 F.2d 798, 800-01 (10th Cir.), cert. denied, 447 U.S. 906 (1980); Huey v. Teledyne, Inc., 608 F.2d 1234, 1239 (9th Cir. 1979).

18 See text and notes at notes 123-128 infra.

49 370 F.2d 119 (2d Cir. 1966), cert. denied, 386 U.S. 1035 (1967).

so See text at note 59 infra. For an analysis of the death knell doctrine, see Comment, Appealability of a Class Action Dismissal: The "Death Knell" Doctrine, 39 U. CHI. L. Rev. 403 (1972). See also Cohen, "Not Dead But Only Sleeping": The Rejection of the Death Knell Doctrine and the Survival of Class Actions Denied Certification, 59 B.U.L. REv. 257 (1979); Note, Appealability of Class Action Determinations, 44 FordhAM L. REv. 548 (1975).

B1 Odd-lot stocks are those stocks traded in groups of less than 100 shares. For a complete history of this complex litigation, see Eisen v. Carlisle \& Jacquelin, 417 U.S. 156, 159-69 (1974). 
spired and combined to monopolize odd-lot trading and had charged excessive fees in violation of federal antitrust laws. The representative plaintiff's individual stake in the damage award was only $\$ 70$; the court recognized that "no lawyer of competence is going to undertake this complex and costly case to recover $\$ 70 .{ }^{\prime 32}$

The Second Circuit relied on two Supreme Court decisions, Cohen $v$. Beneficial Industrial Loan Corp. ${ }^{\mathrm{ss}}$ and Gillespie $v$. United States Steel Corp., ${ }^{54}$ as authority for a practical interpretation of section 1291. The Court in Cohen articulated an exception to the final judgment rule known as the collateral order doctrine. The district court had refused to grant a corporation's motion to require the plaintiff in a stockholder's derivative suit to post a security bond for the defendants' reasonable expenses relating to the litigation. The Supreme Court declared that the final judgment rule embodied in section 1291 was designed to "disallow appeal from any decision which is tentative, informal or incomplete. . . . So long as the matter remains open, unfinished or inconclusive, there may be no intrusion by appeal." serted that section 1291 should be given a "practical rather than a technical construction" ${ }^{156}$ and held that the district court's denial of the corporation's motion "appears to fall in that small class which finally determines claims of right separable from, and collateral to, rights asserted in the action, too important to be denied review and too independent of the cause itself to require that appellate consideration be deferred until the whole cause is adjudicated." In In Gillespie, the Court expanded the "small class" of decisions covered under the collateral order doctrine by accepting jurisdiction over a district court ruling that, although not a final judgment on the merits, was " fundamental to the further conduct of the case." "58

82370 F.2d at 120 .

s3 337 U.S. 541 (1949).

379 U.S. 148 (1964).

ss 337 U.S. at 546.

ss Id. The Court stated that practical construction of the final judgment rule had a long tradition, relying on Cobbledick v. United States, 309 U.S. 323 (1940); United States v. River Rouge Improvement Co., 269 U.S. 411, 414 (1926); and Bank of Columbia v. Sweeny, 26 U.S. (1 Pet.) 567, 569 (1828).

3233 U.S. at 546.

ss 379 U.S. 148, 154 (1964) (quoting United States v. General Motors Corp., 323 U.S. 373,377 (1945)). The order in question was the grant of a motion to strike the plaintiff's wrongful death claim under state law. The plaintiff's claim under the Jones Act, 46 U.S.C. $\S 688$ (1976), was not affected by the motion to strike. 
The Second Circuit in Eisen went beyond the collateral order doctrine as developed in Cohen and Gillespie. It held that "[w] here the effect of a district court's order, if not reviewed, is the death knell of the action, review should be allowed." the denial of class certification was not a technical final judgment, because the denial could be modified by the district court and the plaintiff's $\$ 70$ claim was still pending, the Second Circuit recognized that for all practical purposes, the adverse class determination ended the suit. To prevent injustice, the court reviewed the order as a practical final judgment.

The defendant in Eisen argued that under Oppenheimer $v$. F.J. Young \& Co., ${ }^{60}$ a class determination should be reviewed only after a technical final judgment. In Oppenheimer, the district court denied class certification but allowed the representative plaintiffs to amend their complaint. The plaintiffs purposely elected not to amend, and the district court dismissed the complaint "in its entirety." utory class certification denial and the final dismissal of the complaint. The Second Circuit reviewed the final dismissal and held that the class had been decertified erroneously. ${ }^{62}$ Writing for the court, Judge Augustus Hand noted that the dismissal was final as to the class members; thus the adverse class determination merged with the final judgment and was subject to appellate review. ${ }^{63}$ The court would not review the interlocutory class certification denial, however, because the district court had sustained the representative plaintiffs' individual claims, and leave to amend was available. ${ }^{64}$ The dismissal of the complaint "in its entirety" was a technical final judgment. ${ }^{65}$ By refusing to review the amendable

30 370 F.2d at 121.

so 154 F.2d 387 (2d Cir. 1944).

-1 Id. at 388 .

62 Id. at $388-90$.

cs Id. at 388 .

Id.

os Judge Hand effectively decided the case pursuant to FED. R. Crv. P. 54(b), under which a final judgment could be entered as to some litigants in a multiparty claim. The intent of rule 54(b) was not to circumvent the final judgment rule but to allow interlocutory review in cases with multiple parties where there might be an injustice if review had to await adjudication of the entire case. See Advisory Comm. on Rules for Civil Procedure, Report of Proposed Amendments to Rules of Civil Procedure, 5 F.R.D. 433, $472-73$ (1946). Subsequent to Oppenheimer, rule 54(b) was amended to make review discretionary. Id. at 473 (Oppenheimer cited as illustrative of the problems inherent in rule 54(b)).

When Oppenheimer was decided in 1944, however, rule 54(b) review was not discretionary. It was as much a technical final judgment for the class as a dismissal for want of prose- 
class certification denial, the Court implicitly decided that anything less than a technical final judgment was not sufficiently final for review.

Eisen distinguished Oppenheimer as having been decided prior to the establishment of the collateral order doctrine in $\mathrm{Co}$ hen. ${ }^{68}$ Oppenheimer had adopted a technical reading of the final judgment rule and therefore was inconsistent with the practical view espoused in Cohen and subsequently extended in Eisen.

The continuum of finality illustrates the differences between these pre-Livesay cases. Under Oppenheimer, only those decisions at the technical final judgment terminal could be reviewed. The Cohen collateral order doctrine allowed something less than a technical final judgment to be reviewed if certain conditions were met. Gillespie expanded the class of reviewable decisions, permitting review of a judgment closer to the practical final judgment terminal. Finally, Eisen effectively held that the entire continuum was reviewable because even a decision at the practical final judgment terminal was sufficiently final for review.

\section{B. Livesay}

In Coopers \& Lybrand v. Livesay, ${ }^{67}$ the Supreme Court in effect was asked to find that a practical final judgment, in this case an adverse class determination in a negative incentive situation, was sufficient to trigger appellate review under section 1291 as a matter of right. The Court unanimously rejected the view that the judgment was appealable under either the collateral order doctrine or the death knell doctrine, holding the former inapplicable to the case $^{68}$ and the latter an improper exception to the final judgment rule. ${ }^{69}$

The representative plaintiffs in Livesay had relatively small individual claims, ${ }^{70}$ and a class action was the only feasible route

cution under rule 41 (b) is now a technical final judgment for both the individual plaintiff and the class.

38 370 F.2d at 120.

${ }^{67} 437$ U.S. 463 (1978).

68 Id. at 468-69.

${ }^{89}$ Id. at 476-77.

70 The petitioner, an accounting firm, had certified financial statements in a prospectus issued in conjunction with a public offering of securities. Respondents bought the securities in reliance on the prospectus, but the earnings reported therein were not the same as the actual earnings. Respondents claimed to have lost $\$ 2,650$ when they sold the securities, and they alleged securities fraud. 
to litigation. The district court first certified, then decertified the plaintiff class. ${ }^{71}$ Invoking the death knell doctrine, the Eighth Circuit accepted jurisdiction and reversed the district court's denial of class certification. ${ }^{72}$ The defendants appealed, and the Supreme Court reversed, holding the district court's order not appealable as a final judgment.

The Court dismissed the plaintiffs' claim that review should be granted under the collateral order doctrine. Writing for the Court, Justice Stevens argued that to fit in the "small class" established in Cohen, "the order must conclusively determine the disputed question, resolve an important issue completely separate from the merits of the action and be effectively unreviewable on appeal from final judgment." 73 He concluded that a class action determination was subject to revision by the district court, integrally linked to the merits of plaintiffs' claim, and subject to effective review after final judgment on appeal either by the representative plaintiffs or by intervening class members. ${ }^{74}$ Despite the fact that the third conclusion begs the negative incentive question, the Court held that a class certification decision is not reviewable under the collateral order doctrine. ${ }^{75}$

Justice Stevens then turned to the question of review under the death knell doctrine. That doctrine applies specifically to an adverse class determination in a negative incentive situation, whereas the collateral order doctrine is applicable to any important, yet unreviewable issue, separate from the merits of the action. In a sense, the death knell doctrine is a refined collateral order doctrine addressed to the negative incentive predicament. Having found the collateral order doctrine inapplicable to adverse class determinations, it is not surprising that the Court held the death knell doctrine to be an inappropriate exception to section $1291 . .^{76}$ Recognizing the policy considerations on both sides of the issue, ${ }^{77}$ Justice Stevens concluded that they were matters for legis-

72 See 437 U.S. at 466.

72 Livesay v. Punta Gorda Isles, Inc., 550 F.2d 1106 (8th Cir. 1977).

7s 437 U.S. at 468 (emphasis added).

76 For support, the opinion cited United States v. McDonald, 432 U.S. 385 (1977). See text and notes at notes 119-120 infra.

75437 U.S. at 469 .

7d. at $476-77$.

77 On the one hand, class actions serve a vital role in providing an opportunity for individuals with small claims to gain access to the courts. See Kirkpatrick, Consumer Class Litigation, 50 OR. L. REv. 21 (1970); Schuck \& Cohen, The Consumer Class Action: An Endangered Species, 12 SAN DIEgo L. Rev. 39, $42-43$ (1974). On the other hand, class ac- 
lative rather than judicial concern. ${ }^{78} \mathrm{He}$ criticized the death knell doctrine for being dependent upon a court's uncertain perception of the economic impact of adverse class determinations on representative plaintiffs. "[I]f the court believes that the plaintiff has adequate incentive to continue, the order is considered interlocutory; but if the court concludes that the ruling, as a practical matter, makes further litigation improbable, it is considered an appealable final decision." "79

The primary focus of Justice Stevens's criticism of the death knell rule concerned its serious " 'debilitating effect" "80 on the administration of justice. He asserted that the doctrine allows for "indiscriminate interlocutory review of decisions made by the trial judge,"81 contrary to the restricted scope of interlocutory review under section 1292(b)..$^{82}$ The doctrine would thrust appellate courts into a fact-finding role to decide the appealability of individual class actions. "[T] $]$ he fact that an interlocutory order may induce a party to abandon his claim before final judgment," he declared, "is not sufficient reason for considering it a 'final decision' within the meaning of section 1291."83

The Court in Livesay was more concerned about the problems of piecemeal appeals than the possible injustices done to individual parties. Rather than rely on the practical construction standard to interpret section 1291, , $^{\text {s }}$ the Court stated:

Although a rigid insistence on technical finality would sometimes conflict with the purposes of the statute, . . . even adherents of the "death knell" doctrine acknowledge that a refusal to certify a class does not fall in that limited category of orders, which, though nonfinal, may be appealed without undermining the policies served by the general rule. ${ }^{80}$

tions can be used to harass an otherwise innocent defendant into settlement. See Handler, The Shift From Substantive to Procedural Innovations in Antitrust Suits-The TwentyThird Annual Antitrust Review, 71 Colum. L. Rev. 1, 8-9 (1971); Simon, Class Actions-Useful Tool or Engine of Destruction, 55 F.R.D. 375 (1974).

78437 U.S. at 470.

79. Id 471 .

so Id. (quoting Eisen v. Carlisle \& Jacquelin, 417 U.S. 156, 170 (1974)).

s1 437 U.S. at 474 (emphasis in original).

${ }^{82}$ Id. See also H.R. REP. No. 1667, 85th Cong., 2d Sess. 4-6 (1958); Note, supra note 18, at $610-12$.

ss 437 U.S. at 477 .

84 See text and notes at notes 38-39 supra.

ss 437 U.S. at 471 (citation omitted). 
The continuum of finality illustrates the fundamental disagreement between Livesay and Eisen. Whereas Eisen decided that a practical final judgment was sufficiently final for review, Livesay held that it was not, thereby effectively overruling Eisen. ${ }^{86}$ Moreover, while Livesay can be read as holding that any technical final judgment is appealable, it also is possible to interpret the decision as precluding appeal of even a technical final judgment where review would undermine the general policy against piecemeal appeals.

\section{Livesay's Progeny}

Even though dismissals pursuant to rule 41(b) are technical final judgments, two circuit courts of appeals have extended Livesay to preclude review of such dismissals when coupled with adverse class determinations. These decisions effectively have held that not even technical finality is sufficient to guarantee review.

1. Huey v. Teledyne, Inc. ${ }^{87}$ In Huey, the representative plaintiff failed to appear at trial after the district court denied class certification. The district court, sua sponte, dismissed the suit with prejudice under rule 41 (b) for want of prosecution. ${ }^{88}$ On appeal, the Ninth Circuit denied review of the adverse class determination, arguing that Livesay's "policy against piecemeal appeals applies to this case even though a final judgment has been entered." piecemeal appeals precludes the appeal of an order denying class certification-even where that may sound the 'death knell' of an action-so it precludes review of that order from a proper dismissal for failure to prosecute which results from that order."9o

Livesay stated that "an order denying class certification is subject to effective review after final judgment at the behest of the named plaintiff or the intervening class members,"91 and the Ninth

36 Livesay did not discredit the collateral order doctrine, so some decisions that are not at the technical final judgment terminal remain subject to review.

${ }^{87} 608$ F.2d 1234 (9th Cir. 1979).

as Id. at 1236. The district court originally dismissed the suit without prejudice but changed the dismissal to one with prejudice after the defendant's motion for correction of the order. The Ninth Circuit upheld the dismissal with prejudice as within the lower court's discretion. The appellate court also approved the change as a correction of a clerical mistake in the judgment, pursuent to FED. R. Crv. P. 60(a). 608 F.2d at 1236-38.

so 608 F.2d at 1239.

90 Id.

91437 U.S. at 469 . See text and note at note 74 supra. 
Circuit itself had held previously that interlocutory orders, including adverse class determinations, merge with final orders and are reviewable on appeal. ${ }^{.2}$ Nonetheless, Huey carved out a special exception to the merger rule for situations in which the interlocutory order caused the dismissal for failure to prosecute..$^{93}$ In doing so, the court rejected ${ }^{94}$ the Second Circuit's reasoning in Allied Air Freight, Inc. v. Pan American World Airways, Inc., ${ }^{95}$ which relied upon a technical reading of section $1291^{96}$ to reverse an interlocutory stay order following a dismissal for want of prosecution. Despite arguments concerning the "orderly administration of justice,"97 and although the plaintiff had acquiesced in the dismissal in order to obtain review of the interlocutory stay order, ${ }^{98}$ the Second Circuit held that an involuntary dismissal is an appealable final decision. The court stated that "[s]ince all interlocutory orders and decrees are merged into the final order of the district court," ${ }_{99}$ the interlocutory stay order could be reviewed with the final order on appeal.

In rejecting Allied Air, Huey explicitly endorsed the rationale of the Third Circuit in Sullivan v. Pacific Indemnity Co. ${ }^{100}$ and the Sixth Circuit in Hughley v. Eaton Corp. ${ }^{101}$ that technical final judgments are not sufficient to obtain review as a matter of right if suffered to obtain review of an otherwise nonreviewable practical final judgment. ${ }^{102}$ Sullivan characterized this strategy as an "attempt to avoid the court's firm position against interlocutory ap-

92 Fendler v. Westgate-Cal. Corp., 527 F.2d 1168, 1170 (9th Cir. 1975) (per curiam) (granting review of an interlocutory order denying class certification that had merged with a dismissal under rule 41(b) for failure to obey a court order). See also Sackett v. Beaman, 399 F.2d 884, 889 n.6 (9th Cir. 1968).

33608 F.2d at 1240 .

of Id. at 1239.

os 393 F.2d 441 (2d Cir.), cert. denied, 393 U.S. 846 (1968). The district court issued an order providing that unless the plaintiff took action within 90 days, the suit would be dismissed for want of prosecution. The plaintiff refused to do so, and the district court, sua sponte, dismissed the suit. The plaintiff previously had been denied both a writ of mandamus and an interlocutory certification order under section 1292(b). Failure to prosecute, therefore, was the only remaining way to obtain review of the stay order. Id. at 443.

See id. at 444 .

97 Id.

98 The plaintiff did "not deny that the reason no action was taken to avoid dismissal

. . . was to obtain review of the interlocutory order granting the stay." Id.

92 Id.

${ }^{100} 566$ F.2d 444 (3d Cir. 1977) (per curiam).

${ }^{103} 572$ F.2d 556 (6th Cir. 1978) (per curiam).

102608 F.2d at 1239. 
peals of class certification determinations."103 Hughley added that where plaintiffs make a "conscious choice" to suffer dismissal for want of prosecution, finality should not be used as an "avenue for reaching issues which are not subject to interlocutory appeal as of right."104

2. Bowe v. First of Denver Mortgage Investors. ${ }^{105}$ The Tenth Circuit in this case also found the purpose behind an otherwise technical final judgment relevant in considering review of an interlocutory order. A paradigmatic negative incentive case, ${ }^{106}$ Bowe involved a 6,000-member class that held beneficiary interests in the defendant. The representative plaintiff, whose individual claim was approximately $\$ 2,300$, alleged, inter alia, a conspiracy in violation of federal securities law. ${ }^{107}$ The district court refused to certify the

${ }^{103} 566$ F.2d at 445. The court relied on its earlier decision in Marshall v. Sielaff, 492 F.2d 917 (3d Cir. 1974), to deny review. The Third Circuit quoted from Marshall as follows: If a litigant could refuse to proceed whenever a trial judge ruled against him, wait for the court to enter a dismissal for failure to prosecute, and then obtain review of the judge's interlocutory decision, the policy against piecemeal litigation and review would be severely weakened. This procedural technique would in effect provide a means to avoid the finality rule embodied in 28 U.S.C.A. $\$ 1291$. To review the district court's refusal . . . under the facts of this case is to invite the inundation of appellate dockets with requests for review of interlocutory orders and to undermine the ability of trial judges to achieve the orderly and expeditious disposition of cases.

Marshall v. Sielaff, 492 F.2d 917, 919 (3d Cir. 1974), quoted in Sullivan v. Pacific Indem. Co., 566 F.2d 444, 445-46 (3d Cir. 1977) (per curiam).

Marshall can be distinguished from the negative incentive situation, where the representative plaintiff cannot economically justify proceeding with the litigation regardless of the strength of his case on the merits. In Marshall, on the other hand, the district court denied a writ of habeas corpus for the appearance of three prison inmates as witnesses on behalf of the plaintiff. The plaintiff refused to proceed on the ground that the witnesses were essential to his case; thus, his decision was made not because of an external factor, but because the merits of the litigation were weakened by the district court's order.

104572 F.2d at 557.

${ }^{108} 613$ F.2d 798 (10th Cir.), cert. denied, 447 U.S. 906 (1980). The suit originally was raised in 1976, No. 75-M-350 (D. Colo. Mar. 16, 1976) (on file with The University of Chicago Law Review), where the district court denied class certification. The plaintiff appealed the denial and lost, 562 F.2d 640 (10th Cir. 1977). On remand to hear the individual claim, the plaintiff again tried to obtain class certification, was denied, and purposely suffered a rule 41 (b) dismissal. It is the appeal from that dismissal that is analyzed. See text at notes 111-114 infra.

106 Bowe's attorney, however, admitted on the record that Bowe could continue the litigation if the class was not certified, 562 F.2d at 643 (10th Cir. 1977) (first appeal), an admission contrary to Bowe's later argument.

${ }^{107}$ No. 75-M-350 (D. Colo. Mar. 16, 1976) (order denying class certification) (on file with The University of Chicago Law Review). The suit alleged violations of section $10(\mathrm{~b})$ of the Securities Exchange Act of 1934, 15 U.S.C. $\S 78$ j(b) (1976), and rule 10b-5, 17 C.F.R. $240.10 \mathrm{~b}-5$ (1980), as promulgated thereunder; common law fraud principles; and the Colorado Securities Act, CoLo. REv. STAT. § 11-51-125 (1973). The plaintiff sought compensatory 
class, characterizing the plaintiff's allegations as mere "conjurations." 108 After being denied class certification, the representative plaintiff sought immediate review under section 1291, invoking both the collateral order doctrine and the death knell doctrine. The Tenth Circuit concluded that neither applied and refused to review the adverse class determination. ${ }^{100}$

On remand, the district court again denied the representative plaintiff's motion to certify the class. When the plaintiff refused to pursue the individual claim, the trial court dismissed the action with prejudice for want of prosecution. ${ }^{110}$ Reviewing the case for the second time, ${ }^{111}$ the Tenth Circuit admitted that "[u]ndoubtedly, the dismissal of the plaintiffs' complaint for failure to prosecute was a final order which could not become much more final."112 Nevertheless, the court reasoned that Livesay ended the death knell exception to section 1291 and contended that Bowe was identical to Livesay, because in both cases the representative plaintiffs sought to circumvent the final judgment rule. ${ }^{113}$ The court asserted that "[ $t]$ he only addition which can be pointed to in our case is a graphic demonstration that the 'death knell' had indeed sounded,"114 a distinction insufficient to distinguish Bowe from Livesay.

Recognizing that the effect of Huey and Bowe is to eliminate "any review of orders which deny class certification where review may be necessary to avoid injustice,"115 the Tenth Circuit admitted that "[p]erhaps the Supreme Court did not contemplate this situation in Livesay." "116 Because Livesay "only considered the interloc-

damages for herself and the class, as well as declaratory and injunctive relief.

${ }^{108}$ No. 75-M-350 (D. Colo. Mar. 16, 1976) (on file with The University of Chicago Law Review).

${ }^{102} 562$ F.2d 640 (10th Cir. 1977).

110613 F.2d at 799. Although the court does not specifically mention rule 41(b), one can assume that by dismissing the suit in this way, the court was relying on that rule.

'i11 Livesay was decided after the Tenth Circuit's first consideration of Bowe. The second Bowe decision noted that "the only issue that is properly before us is whether the fact situation in the case at bar constitutes an exception to the Livesay doctrine." Id. at 800 .

112 Id. at 799.

113 Id. at 800 .

$314 I d$.

11s Id. The court noted that

[i]n a situation where the individual claims of class members are actually too infinitesimal to warrant individual litigation and the refusal to prosecute is not a ploy which seeks to develop a way around the Livesay doctrine, the plaintiff has only one way to Id. go and that route is by way of a class action.

116 Id. at 801-02. 
utory character of the appeal under $\S 1291$," the Bowe court recognized the possibility that the Supreme Court "did not intend to totally preclude review of the class issue ... in situations where the plaintiff is unable to go forward following the denial of certification."117 Nevertheless, the court joined the Ninth Circuit in Huey ${ }^{118}$ by extending Livesay to preclude review of dismissals under rule 41(b) suffered to obtain review of adverse class determinations.

\section{Applicability of Livesay to Rule 41(b)}

In United Airlines, Inc. v. McDonald, ${ }^{119}$ the Supreme Court held that adverse class determinations are reviewable upon entry of a technical final judgment. ${ }^{120}$ Dismissals pursuant to rule $41(\mathrm{~b})$ traditionally have been viewed as technical final judgments. ${ }^{121}$ In extending Livesay to encompass rule 41(b) dismissals for want of prosecution, Huey and Bowe emphasized the representative plaintiffs' motives to justify shifting such dismissals from the technical final judgment terminal to an intermediate position along the continuum of finality.

This shift is unjustified. Livesay involved solely an adverse class determination, which is at most a practical final judgment. It did not consider dismissals under rule 41 (b) and declared only that the death knell doctrine was invalid because adverse class determinations, standing alone, are insufficiently final to meet the requirements of section $1291 .^{122}$

Moreover, Livesay's policy against piecemeal appeals ${ }^{123}$ and its concern for the difficulties in assessing the validity of death knell claims $^{124}$ are not applicable to dismissals entered under rule 41(b). The Ninth and Tenth Circuits' concern about the erosion of the Livesay doctrine would be justified if rule 41 (b) dismissals were suffered routinely to circumvent the finality rule. Under the Eisen death knell doctrine, such a fear of piecemeal appeals was justified

\footnotetext{
${ }^{217}$ Id.

11 See text and notes at notes 87-104 supra.

110432 U.S. 385 (1977).

120 Id. at 393-94. See Deposit Guar. Nat'l Bank v. Roper, 445 U.S. 326, 336 (1980).

121 See Petty v. Manpower, Inc., 591 F.2d 615 (10th Cir. 1979); Elfenbein v. Gulf \& W. Indus., Inc., 590 F.2d 445 (2d Cir. 1978); Anderson v. Air W., Inc., 542 F.2d 522 (9th Cir. 1976). See generally 5 J. Moors, supra note 9, I 41.11[2].
}

122437 U.S. at 477.

123 See text at notes 80-83 supra.

124 See text at note 79 supra. 
because death knell appeals could be shams. ${ }^{125}$ There is little danger, however, that a representative plaintiff will claim falsely that he cannot proceed with the individual action in the rule $41(\mathrm{~b})$ situation. Unlike appeal under the death knell doctrine, a dismissal pursuant to rule $41(\mathrm{~b})$ is an adjudication on the merits: if the dismissal is not reversed, the representative plaintiff loses his individual claim without any opportunity to litigate the merits of the question. ${ }^{128}$

In addition, once the claim is dismissed, res judicata bars the plaintiff from raising the claim again. ${ }^{127}$ Representative plaintiffs who attempt to circumvent the final judgment rule risk their claims for the sake of the class by suffering a dismissal under 41(b). Because representative plaintiffs do not take this risk lightly, the threat of such a dismissal enables courts to distinguish false death knell claims from ones that accurately reflect economic realities. This res judicata risk separates bona fide negative incentive plaintiffs from those plaintiffs who seek to use the death knell doctrine unjustly to obtain interlocutory review.

Unlike the death knell appeal, rule 41(b) dismissal imposes no additional burdens on the judicial system; the representative plaintiff has only one chance to appeal both the individual and class claims. ${ }^{128}$ Rule 41 (b) dismissals also eliminate the Livesay concern

${ }^{125}$ For example, a representative plaintiff who has sufficient economic incentive to pursue his individual claim to a full trial on the merits could attempt to obtain immediate review of an adverse class determination by claiming falsely that the denial of class certification had sounded the "death knell" of the action. See, e.g., Graci v. United States, 472 F.2d 124, 126 (5th Cir. 1973) (denial of class action certification not reviewable under death knell doctrine where representative plaintiffs sought $\$ 78,700$ in individual damages); Weingartner v. Union Oil Co., 431 F.2d 26, 29 (9th Cir. 1970) (denial of class certification not reviewable under death knell doctrine where individual claims aggregate $\$ 353,700$ ), cert. denied, 400 U.S. 1000 (1971); Caceres v. International Air Transp. Assoc., 422 F.2d 141, 144 (2d Cir. 1970) (death knell doctrine should not be extended to review denial of class certification where average individual claim is $\$ 150,000$ ).

${ }^{128}$ At least one court was not disturbed by the fact that some representative plaintiffs would be unable to litigate potentially valid claims if class certification were denied and appeal were unavailable. "Our scarce federal judicial resources cannot be allocated on the assumption that they must provide a forum for the vindication of every individual wrong however slight." Hackett v. General Host Corp., 455 F.2d 618, 626 (3d Cir.), cert. denied, 407 U.S. 925 (1972).

${ }^{127}$ Bowe v. First of Denver Mortgage Investors, 613 F.2d 798, 801, 802 (10th Cir.), cert. denied, 447 U.S. 906 (1980); Huey v. Teledyne, Inc., 608 F.2d 1234, 1240 (9th Cir. 1979).

${ }^{128}$. For example, if a representative plaintiff were granted review of the adverse class determination under the death knell doctrine and lost on appeal, he could (assuming this was a false death knell claim) continue litigating the individual claim to a full trial on the merits. If he lost the claim, he could then appeal the individual final judgment. Under a rule 
that courts not base their rulings on uncertain perceptions of class action economics. By risking forfeiture of their claims, plaintiffs demonstrate the severe economic disincentives of adverse class determinations. The rule 41(b) dismissal means that the death knell has sounded, that a final order has been entered, and that the adverse class determination has induced abandonment of the claim.

A dismissal under rule 41(b) traditionally has been considered to fulfill the requirements of section 1291; this tradition should be maintained. Denying review in negative incentive situations to representative plaintiffs who take an "all or nothing risk that the district court's order will be reversed"129 is a far greater injustice than denying review in the death knell situations contemplated by Livesay. If a rule 41 (b) dismissal is considered sufficiently final to bring an end to the plaintiff's individual claim, the dismissal should be sufficiently final to warrant appellate review as a matter of right. There is, therefore, no justification for creating an exception to the final judgment rule that would deny review to the representative plaintiff in a negative incentive situation who suffers dismissal under rule $41(\mathrm{~b})$.

\section{Rule 41(b) Review in Practice}

Although a court should review an adverse class determination when coupled with a rule 41 (b) dismissal, rule 41 (b) still must be considered an action of last resort for the plaintiff. The chances that the district court will be reversed on both the class determination and the rule 41 (b) dismissal are very slim. ${ }^{130}$ Both denial of class certification ${ }^{131}$ and dismissal for want of prosecution ${ }^{132}$ are decisions within the discretion of the trial court and thus are subject to an "abuse of discretion" standard of review. ${ }^{13 s}$

41(b) dismissal, however, if the negative incentive plaintiff lost on appeal, the class certification question and the individual claim would be terminated together.

129 Note, supra note 50 , at 574.

${ }^{130}$ Cohen, supra note 50, at 294.

${ }^{131}$ Fendler v. Westgate-Cal. Corp., 527 F.2d 1168, 1170 (9th Cir. 1975) (per curiam); In re Cessna Aircraft Distrib. Antitrust Litigation, 518 F.2d 213, 215 (8th Cir.), cert. denied, 423 U.S. 947 (1975); Clark v. Watchie, 513 F.2d 994, 1000 (9th Cir.), cert. denied, 423 U.S. 841 (1975); Foster v. Sparks, 506 F.2d 805, 808 (5th Cir. 1975); 3B J. MooRE, supra note 9, ก 23.50 .

132 Lopez v. Aransas County Indep. School Dist., 570 F.2d 541, 544 (5th Cir. 1978); Anderson v. Air W., Inc., 542 F.2d 522, 524 (9th Cir. 1976); Theilmann v. Rutland Hosp., Inc., 455 F.2d 853, 855 (2d Cir. 1972) (per curiam); 5 J. Moore, supra note 9, I 41.11[2].

${ }_{133}$ Ramsay v. Bailey, 531 F.2d 706, 707-08 (5th Cir. 1976) (per curiam), cert. denied, 429 U.S. 1107 (1977); Dyotherm Corp. v. Turbo Mach. Co., 392 F.2d 146, 148 (3d Cir. 1968). 
Moreover, even if the court of appeals finds that the district court erred in denying class certification, the representative plaintiff deliberately caused the dismissal by failing to proceed with the litigation. It would seem that in such a case the district court acted within its discretion in dismissing the suit. Thus the representative plaintiff is forced to take an untenable position. At the trial level, he must seek to have the case dismissed; at the appellate level, however, he must argue that the district court abused its discretion by dismissing the action.

To resolve this dilemma, the courts should permit plaintiffs to raise the propriety of class certification decisions as an affirmative defense to rule $41(\mathrm{~b})$ dismissals. Analogous procedures are used in other areas of the law. In labor law, for example, an employer cannot obtain direct judicial review of the National Labor Relations Board's determination of a collective bargaining unit. ${ }^{134}$ Rather, it must refuse to bargain collectively with the employees' representatives, suffer an unfair labor practice judgment before the National Labor Relations Board, ${ }^{135}$ and then seek judicial review. On appeal, the employer may defend its refusal to bargain by demonstrating that the bargaining unit determination was improper. ${ }^{136}$ If this defense succeeds, the unfair labor charge is dismissed.

The law of criminal contempt provides a similar analogy. If a court orders a witness to reveal information and the witness believes compliance would cause irreparable injury, he can refuse to comply and invite a charge of criminal contempt. ${ }^{137}$ If the witness is successful in demonstrating on appeal that the court order is invalid, the contempt charge is dismissed. ${ }^{138}$

See also notes 131-132, supra.

134 Magnesium Casting Co. v. NLRB, 401 U.S. 137, 139 (1971); NLRB v. Big Three Indus., Inc., 602 F.2d 898, 901 \& n.2 (9th Cir. 1979); Pacific S.W. Airlines v. NLRB, 587 F.2d 1032, 1035 \& n.3 (9th Cir. 1978); NLRB v. Saint Francis College, 562 F.2d 246, 248 \& n.1 (3d Cir. '1977); Local 1325, Retail Clerks Int'l Ass'n v. NLRB, 414 F.2d 1194, 1196 n.2 (D.C. Cir. 1969). Direct judicial review of a representation issue is available if the NLRB clearly has exceeded its statutory authority, see Leedom v. Kyne, 358 U.S. 184 (1958).

135 The unfair labor practice charge results from the employer'srefusal "to bargain collectively with the representatives of his employees." Labor Management Relations Act, § 8(a)(5), 29 U.S.C. $\S 158(a)(5)$ (1976). The jurisdiction of the NLRB and the extent of judicial review is governed by $\S 10(f)$ of the Act, 29 U.S.C. $\S 160(f)$ (1976).

${ }^{136}$ See authorities cited in note 134 supra.

137 E.g., Maness v. Meyers, 419 U.S. 449 (1975).

${ }^{138}$ Id. Maness was concerned with protecting the witness's fifth amendment privilege against self-incrimination. In United States v. Dickinson, 465 F.2d 496, 512 (5th Cir. 1972), the Fifth Circuit sought to protect against the surrender of any constitutional right. The Fifth Circuit explicitly has extended the Maness and Dickinson rationales to protect "other 
These procedures for review should inform a court's judgment in analyzing rule 41 (b) dismissals. The representative plaintiff who suffers such a dismissal, like the employer who suffers an unfair labor practice charge and the witness who subjects himself to criminal contempt, risks a penalty to secure review of the underlying claim. Review should be limited solely to the merits of that claim. Therefore, if a representative plaintiff can demonstrate that the adverse class determination was improper, the rule 41 (b) dismissal should be reversed.

\section{Conclusion}

In a negative incentive situation, litigation must proceed as a class action or it will not proceed at all. If class certification is denied, the representative plaintiff seeks immediate appellate review as a matter of right. If review under section $1292(\mathrm{~b})$, mandamus, or rule $54(\mathrm{~b})$ is not available, the representative plaintiff will be forced to abandon the suit and suffer a dismissal pursuant to rule 41(b) for lack of prosecution.

This comment has demonstrated that it is a grave injustice to deny review of adverse class certification decisions that have merged with rule $41(\mathrm{~b})$ dismissals. This procedure is the last resort for plaintiffs in negative incentive situations. Such plaintiffs who invite a rule 41 (b) dismissal maintain the integrity of the final judgment rule and do not place additional burdens on the judicial system. Therefore, appellate courts should consider a rule 41(b) dismissal for want of prosecution a final, appealable judgment, even when the dismissal is taken solely to obtain review of an adverse class determination.

Albert F. Cacozza Jr.

rights or privileges, such as the attorney-client privilege and the attorney-work-product doctrine, where disclosure would cause irreparable injury." In re Grand Jury Proceedings, 601 F.2d 162, 169 (5th Cir. 1979). 